\title{
CRITERIA ANALYSIS OF DEVELOPMENT PARADIGMS IN THE FORMATION OF ECONOMIC POLICY
}

\section{КРИТЕРІАЛЬНИЙ АНАЛІЗ ПАРАДИГМ РОЗВИТКУ ПРИ ФОРМУВАННІ ЕКОНОМІЧНОЇ ПОЛІТИКИ}

\author{
Tetiana Romanova ${ }^{1}$ \\ Liudmyla Davydenko
}

DOI: https://doi.org/10.30525/978-9934-588-15-0-42

\begin{abstract}
The aim of the article is to substantiate the criteria basis for paradigm identification of economic science and analyze its relationship to the formation of modern economic policy. Such identification is possible on the basis of allocation of economic theory paradigm model which reflects the phenomenon of its ability to react to changes in a trajectory of economy development and to reveal and justify new regularities of such development. The paradigm model can have a different perspectives and differentiate the way of economic science development depending on the level of criteria for identification of paradigmatic features of a certain scientific school. If we consider economic paradigms in the sectoral context, the construction of a paradigm model is possible on the basis of most significant directions' differentiation of economic science development, according to the essential principle. In this case, the identification of the paradigm structure of a particular economic theory is based on the level of its influence on the nature of the development of economic thought and economic management processes. It has been determined that the construction of an economic science paradigmatic model is possible by differentiating the study criterion basis by providing three criteria: expanded criterion, specified consolidated criterion, criterion identifying the type of economic agent. The basic paradigm identification has been carried out and the expanded criterion is the most detailed one. It is proved that according to the expanded criterion
\end{abstract}

\footnotetext{
${ }^{1}$ Doctor of Economic Sciences, Associate Professor, International Center of Modern Education, Czech Republic

${ }^{2}$ Candidate of Chemical Sciences, Associate Professor,

Associate Professor at Department of Physics,

Poltava National Technical Yuri Kondratyuk University, Ukraine

(C) Tetiana Romanova, Liudmyla Davydenko
} 
the paradigmatic development of economic science has six main periods, which were characterized by the most significant changes in the economic paradigm: 16th-17th centuries: Mercantilist paradigm; 17th-18th centuries: Physiocratic paradigm; 18th-19th centuries: Classical political economy paradigm, Marxist paradigm; the end of 19th century - the beginning of 20th century: Marginalist paradigm; Neoclassical paradigm; the beginning of 20th to the last quarter of 20th century: Keynesian paradigm; Institutional paradigm; the late of 20th century - modern times: economic paradigm of Evolutionism; System economic paradigm; Synergistic economic paradigm. Using the criterion of identifying the type of economic agent as the core of paradigm development, it is possible to conduct an alternative interpretation of economic doctrines: Neoclassical, Institutional, Evolutionary and Systemic. Understanding the essence of development paradigms is an important condition for conducting qualitative research. Exploring different aspects of economic policy requires choosing the economic paradigm that best meets the challenges facing the economy.

\section{1. Ветуп}

Світова економіка знаходиться в стані постійної диференціації своєї структури, що зумовлено складною дискретністю економічного простору, а також його постійним розвитком. Для покращення розуміння економічних процесів, а також емпіричного підгрунтя їх регулювання, необхідне розширення теоретичних знань в області формування та застосування економічної політики як одного з основних важелів стимулювання адаптації економічного простору до вимог поточного часу, як в локальному, так і глобальному розумінні. Економічна політика являє собою розгалужену систему методів та заходів регулювання економіки країни, яка спирається на наукові знання, а також практичні прецеденти свого застосування. Розуміння сутності парадигм розвитку є важливою умовою проведення якісних наукових досліджень. Розгалуженість наукових шкіл та існування значної кількості парадигм розвитку обумовлюють необхідність їх систематизації, класифікації та виділення основних критеріїв їх відмінності. У сучасних умовах формування економічної політики необхідним $є$ вибір тієї парадигми розвитку, яка найбільше відповідає викликам та завданням, які стоять перед економікою. 
Метою даної статті є обгрунтування критеріальної основи парадигмальної ідентифікації економічної науки та аналіз її взаємозв'язку із формуванням сучасної економічної політики. При цьому побудова парадигмальної моделі економічної науки здійснюватиметься шляхом диференціації критеріальної основи дослідження у вигляді виділення трьох критеріїв: розгорнутого критерію, сутнісного конкретизованого критерію, критерію ідентифікації за типом економічного агенту.

При написанні статті використано такі методи дослідження, як: агрегований історично-логічний підхід; методи логічного узагальнення та наукової абстракції; методи аналізу, синтезу та класифікації; методи системного аналізу та порівняння.

\section{2. Формування поняття парадигми}

Парадигма як поняття пройшла досить тривалий шлях свого формування та трансформації. Така особливість пов'язана з ускладненням диференціації науки як універсального для процесу пізнання явища, та зі складною властивістю об'єктивного прагнення сутності самого поняття «парадигми» до уніфікації та здатності таку уніфікацію фактично уособлювати.

Термін «парадигма» 3 грецького $\pi \alpha \rho \alpha ́ \delta \varepsilon \imath \gamma \mu \alpha$ - модель, зразок,

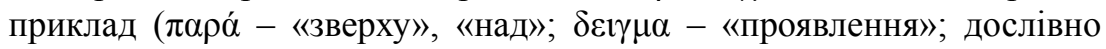
таке поєднання можна розуміти як «те, що визначає характер прояву чого-небудь»). Виникнення поняття «парадигми» відбулося з розвитком філософської думки в стародавній Греції, та пов'язане $з$ такими філософами, як Платон, Аристотель, Геродот та ін., подальший його розвиток відбувся здебільшого в рамках німецької класичної філософії в працях Шелінга та Гегеля, а також інших філософських напрямів та течій. Так, парадигма в філософії використовувалася для характеристики та співвідношення духовної та реальної дійсності, та відповідно ідентифікувалася залежно від особливостей окремих філософських шкіл зі збереженням іiі вихідної сутності, як первообразу та зразку [1, с. 477]. В подальшому термін «парадигма» в процесі розвитку філософії науки був використаний позитивістом Г. Бергманом в значенні характеристики нормативності методології, тобто під парадигмою розумілися загальні принципи та форми дослідження, які виконують нормативну функцію. У філософії науки в рамках розвитку критич- 
ного раціоналізму була здійсненна найбільш розширена конкретизація та обгрунтування терміну парадигма американським науковцем Томасом Куном, що остаточно і закріпило даний термін в науковому обороті, в його класичному вигляді. У своєму дослідженні «Структура наукових революцій» (1962 р.) під парадигмами Т.Кун розумів визнані усіма наукові досягнення, які протягом визначеного часу надають науковому співтовариству модель постановки проблем та їх рішень [2, с. 13]. Тобто, парадигма розуміється як певна сукупність наукових досягнень, які визнаються науковою спільнотою у заданий проміжок часу. Причому поняття парадигми Т. Кун використовує з метою ідентифікації стану «революцій», які виникають в процесі розгортання еволюційного шляху науки, та корегують іiі подальший розвиток. Зміна парадигми являється індикатором виникнення такого стану, та відповідного переходу науки на інший якісний рівень. Отже, виникнення нової фундаментальної теорії, яка являється по суті новою парадигмою, спричиняє трансформуючий вплив на розвиток науки.

Парадигми в такому розрізі мають визначені властивості, до яких слід віднести:

- ендогенну приналежність певної парадигми автономному напрямку науки;

- виникнення парадигми за об'єктною сутністю (певна проблема або їх коло) є інноваційним тобто безпрецедентним;

- відсутність комунікаційних бар'єрів для розуміння та використання сутності та практичних досягнень створеної парадигми.

Фактично парадигми змінюються на границі досягнення критичної маси явищ (проблем-аномалій), які неможливо пояснити в рамках існуючої парадигми. Виникнення нової парадигми частково або повністю замінює сутнісну основу старої щодо вирішення певної проблеми або їх кола, причому методологія нової парадигми несумісна та інноваційна по відношенню до попередньої.

Класичне сприйняття парадигми не виключає альтернативних підходів щодо іiі розуміння, доцільно розглянути їх на окремих прикладах: у загальному сучасному розумінні - це загальновизнана в конкретній науковій спільноті фундаментальна теорія у визначеній області знання [3, с. 201]; в прикладному технологічному аспекті - це напрями технологічних траєкторій, які визначають структуру технологічних змін [4]; 
прояв епістем, який уособлюється в епістемологічних фігурах та являється порогами епістемологізації [5]; науково-дослідницька програма, яка грунтується на єдиних методологічних принципах та проявляється у вигляді відповідної сукупності теорій [6]; домінуюча система теорій та ідей, які обумовлюють бачення світу [7]; наукова картина світу, яка задає узагальнену матрицю системного бачення та створює відповідну дослідницьку програму [8]; панівна система наукових ідей та теорій, які формуються під дією основ науки та диференціюється за рівнями своїх проявів у: загальнонауковому (універсальна), приватному (окрема галузь знань), локальному (окремий регіон або проміжок часу) [9]. Таким чином, можна виокремити спектр ознак парадигмальної ідентифікації процесів розвитку науки за суб'єктною складовою:

- наукові досягнення (ідеї, теорії), які детермінують можливість постановки завдань та вирішення питань;

- наукова картина у вигляді науково-дослідницької програми;

- напрями траєкторій розвитку специфічних науково-галузевих знань;

- домінуючий прояв фундаментальних наукових установок;

- прояв глибинних процесів еволюціонування науки;

- визначальні детермінанти розвитку науки, які можуть проявлятися на різних рівнях іiї існування;

- основи науки, які формують превалюючі ідеали та норми опису та дослідження світу;

- уніфікований за сутністю прояв процесів глобалізації.

Отже, парадигмальну градацію науки можна зобразити у вигляді нижче зображеної схеми (рис. 1). Розглянемо основні наукові революції, які змінювали глобальну наукову парадигму. Найбільш обгрунтовану градацію загальнонаукових парадигм було зроблено С. Стьопіним на основі виділення диференціації та змін основ науки. Основи науки поділяються на:

1. Ідеали та норми дослідження:

- доказовості та обгрунтування знання;

- пояснення та описи;

- побудова та організація знання.

2. Наукова картина світу:

- уява про фундаментальні об'єкти, з яких передбачається побудова всіх інших об'єктів, які досліджує певна наука; 


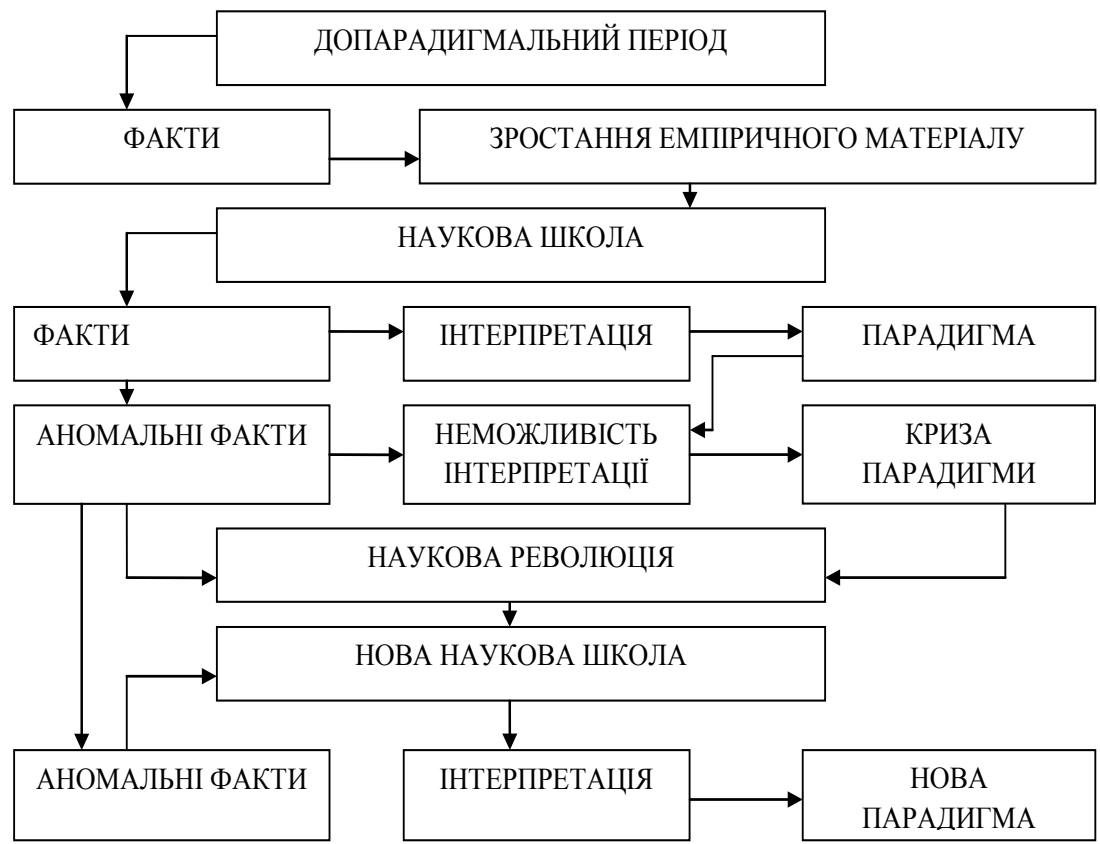

\section{Рис. 1. Парадигмальна градація науки}

Джерело: розроблено автором Романовою Т.В.

- уява про типологію об'єктів, які досліджуються;

- уява про закономірності взаємодії усього спектру об'єктів;

- уява про просторово-часову структуру реальності.

3. Філософські основи науки (філософські ідеї та принципи, які обгрунтовують ідеали та норми і онтологічні постулати науки) [10].

Градації основ науки в часовому просторі утворюють періоди наукових революцій, які розрізняються за сутнісною основою характеристики домінуючої парадигми природознавчої науки (таблиця 1).

Отже, ми розглянули підходи щодо розуміння поняття парадигми та основні етапи глобальних наукових революцій у природознавчих науках. Далі визначимо суто економічні парадигми, які сформувалися в результаті еволюції економічної науки. 


\begin{tabular}{|c|c|c|c|c|}
\hline \multicolumn{5}{|c|}{ Градація основ науки та періоди наукових революцій } \\
\hline Період & $\begin{array}{c}\text { Наукова } \\
\text { революція }\end{array}$ & \begin{tabular}{|c|} 
TиI \\
раціональності \\
(парадигма) \\
\end{tabular} & $\begin{array}{c}\text { Системні } \\
\text { об'єкти }\end{array}$ & Наука \\
\hline $\begin{array}{l}\text { Починаючи } \\
3 \text { XVII ст. }\end{array}$ & Перша & $\begin{array}{c}\text { Класична } \\
\text { раціональність }\end{array}$ & Прості системи & Механіка \\
\hline $\begin{array}{c}3 \text { кінця XVIIIcт. } \\
\text { до першої } \\
\text { половини } \\
\text { XIX ст. } \\
\end{array}$ & Друга & $\begin{array}{c}\text { Дисциплінарно } \\
\text { організована } \\
\text { класична } \\
\text { раціональність } \\
\end{array}$ & Прості системи & Термодинаміка \\
\hline $\begin{array}{c}3 \text { кінця ХІХ ст. } \\
\text { до середини } \\
\text { XX ст. }\end{array}$ & Третя & $\begin{array}{c}\text { Некласична } \\
\text { раціональність }\end{array}$ & $\begin{array}{c}\text { Складні } \\
\text { саморегулюючі } \\
\text { системи }\end{array}$ & Кібернетика \\
\hline $\begin{array}{c}3 \text { останньої } \\
\text { третини XX ст. } \\
\text { до сучасного } \\
\text { часу }\end{array}$ & Четверта & $\begin{array}{c}\text { Постнекласична } \\
\text { раціональність }\end{array}$ & $\begin{array}{c}\text { Складні } \\
\text { саморозвиваючі } \\
\text { системи }\end{array}$ & $\begin{array}{c}\text { Нелінійна } \\
\text { термодинаміка } \\
\text { Хімія } \\
\text { нерівноважних } \\
\text { станів }\end{array}$ \\
\hline
\end{tabular}

Джерело: опраџьовано авторами за джерелом [8]

\section{3. Парадигмальна модель наукових економічних шкіл}

Така ідентифікація можлива на основі виділення парадигмальної моделі економічної теорії, яка відображає феномен її здатності реагувати на зміни в траєкторії розвитку економіки та виявляти і обгрунтовувати нові закономірності такого розвитку. Парадигмальна модель може мати різний вигляд та диференціювати шлях розвитку економічної науки залежно від рівня розгорнутості критеріїв ідентифікації парадигмальних ознак певної наукової школи. На даному етапі здійснимо базову парадигмальну ідентифікацію, застосовуючи найбільш розгорнутий критерій. Якщо розглядати економічні парадигми в галузевому розрізі, то побудова парадигмальної моделі можлива на основі диференціації найбільш суттєвих напрямів розвитку економічної науки, за сутнісним принципом. У даному випадку ідентифікація парадигмальної ознаки певної економічної теорії відбувається на основі рівня її впливу на характер розвитку економічної думки та процесів управління економікою. Історичні періоди, які позначилися виділенням парадигм на основі розгорнутого критерію і відображають диференціації основних економічних шкіл, можна виділити в такому вигляді: 
- XVI-XVII ст.: меркантилістська парадигма;

- XVII-XVIII ст.: фізіократична парадигма;

- XVIII-XIX ст.: парадигма класичної політичної економії; марксистська парадигма;

- кінець XIX - початок XX ст.: маржиналістська парадигма; парадигма неокласицизму;

- початок XX до останньої чверті XX ст.: кейнсіанська парадигма; парадигма інституціоналізму;

- кінець XX - сучасний час: парадигма економічного еволюціонізму; системна економічна парадигма; синергетична економічна парадигма.

Розглянемо більш докладніше особливості проявів кожного з елементів даної парадигмальної моделі. Так, початкові етапи створення економічних парадигм характеризувалися превалюванням суто емпіричного сприйняття економічних процесів та поступово еволюціонували до створення економічних теорій. Парадигма меркантилізму являється першою найбільш суттєвою спробою провести систематизацію емпіричних досліджень в області економіки, з метою виявлення закономірностей та рекомендацій щодо оптимізації ії розвитку. Основними засновниками даної парадигми являються: А. Монкрет'єн, Т. Ман, А. С'єра. Основними положеннями даної парадигми є: обгрунтування науки про багатство як джерело розвитку держави; ідентифікації торгівельного капіталу як основи багатства; детермінація внутрішнього багатства держави системою зовнішньої торгівлі; процес накопичення багатства повинен грунтуватися на науковому розумінні економічних процесів. Основними недоліком являсться обмеженість методології.

Парадигма фізіократії $є$ наступною ланкою еволюції економічної науки, а їі поява стала можлива на основі використання емпіричного матеріалу попередньої парадигми, причому за сутнісною основою між ними наявний антагонізм, що характерно при переході на інший парадигмальний рівень. Дана парадигми розвивалась в працях: Ф. Кене, Анна Робера Жака Тюрго, Жан-Марі Ле Пена. Основними положеннями даної парадигми являються: виявлення сутності «чистого продукту» на основі аналізу взаємодії між суб'єктами економічних відносин; побудова рівноважної моделі звичайного виробництва та ідентифікація господарства як цілісної системи; встановлення детер- 
мінізму економічного розвитку на основі стимулювання сільськогосподарського сектору.

Парадигма класичної політичної економії була заснована та розвинена в працях: А. Сміта, Д. Рікардо, Дж. Мілля, Ж. Сейя. Основними положеннями даної парадигми є: лібералізація процесів управління економічними процесами; виділення ринкових ендогенних чинників розвитку економіки (економічних законів, конкуренції); встановлення пріоритету індустріалізації та стимулювання розвитку промислового сектору; виділення суспільного продукту як основи багатства держави; ідентифікація та виділення економічного циклу як елементу розвитку економіки.

Наступною для розгляду є марксистська парадигма, засновником якої являється К. Маркс. Основними положеннями економічної марксистської парадигми є: встановлення пріоритету праці як основи формування вартості; розмежування поняття вартості та ціни; диференціація вартості на мінову та споживчу; обгрунтування теорії додаткової вартості; диференціація оплати праці на реальну та номінальну; розроблення теорії грошей (диференціація їх функцій на: міри вартості; засобу обігу; засобу нагромадження; засобу платежу; світових грошей) та капіталу (диференціація форм капіталу на постійний та змінний).

Засновниками парадигми маржиналізму являються: У.С. Джевонс, К. Менгер, Л. Вальрас. Основними положеннями даної парадигми $€$ : встановлення пріоритету універсалізації економічної теорії незалежно від властивостей локального економічного простору; виділення понять граничної корисності та граничної продуктивності як основних детермінант формування траєкторії розвитку економічних процесів; суб'єктивний рівень детермінації економічних процесів на основі мотивованої поведінки суб'єктів господарювання; розуміння предмету економічної теорії через пріоритет вирішення оптимальності розподілу обмежених ресурсів.

Неокласична економічна парадигма сформувалася в працях: А. Маршала, Дж. Б. Кларка, В. Парето, А. Пігу, Р. Солоу, М. Фрідмена. Основними положеннями неокласичної парадигми являються: лібералізації процесів управління економікою та необхідність збереження вільної конкуренції; встановлення ендогенного детермінізму розвитку економіки; виявлення основних суб'єктивних мотивів діяльності інди- 
віду за прототипом «людини економічної»; обгрунтування універсальності функціонального аналізу та розгорнуте використання оцінки граничних величин; встановлення пріоритету детермінізму економічної рівноваги та розвитку виробництва за динамікою руху грошової маси; узгодження динаміки зростання валового національного продукту та обсягів грошової маси.

Утворення та розвиток кейнсіанської економічної парадигми відбувалося в працях: Дж. Кейнса, Дж. Робінсона, А. Хансена, П. Сраффи. Основними положення кейнсіанської парадигми являються: заперечення повного саморегулювання економіки; встановлення пріоритету активного регулювання економіки державою; необхідність компенсації розбіжності обсягів сукупного попиту та пропозиції на основі концепції «ефективного попиту»; розгорнуте застосування аналізу макроекономічних показників; розширення функції інвестицій у забезпеченні економічного розвитку; встановлення пріоритету бюджетної політики при здійсненні регулюючого впливу на економіку.

Основними представниками інституціональної парадигми являються: Т. Веблен, У. Мітчел, Дж. Комонс, Дж. Гелбрейт, Я. Тімбереген, Г. Мюрдаль. Базовими положеннями інституціональної парадигми є: розширення границь детермінізму економічного розвитку за межі суто економічного виміру та обгрунтування системи змішаного впливу економічних та позаекономічних факторів; встановлення пріоритету оцінки та регулювання рівня розвитку соціально-економічних інститутів при дослідженні та управлінні економічними процесами; обгрунтування необхідності розроблення соціально спрямованих програм економічного розвитку; встановлення пріоритету науково-технічного прогресу як основи подолання соціальних протиріч; модернізація повинна проявлятись як зростання рівня задоволення соціальних потреб.

Подальша еволюція економічної теорії відбувається на основі суттєвої асиміляції існуючих парадигм та їх кардинального переосмислення, та утворює систему нових економічних парадигм, які синтезували елементи попереднього парадигмального розвитку. Так, розвиток сучасних економічних парадигм позначився утворенням та розвитком еволюційної економічної парадигми. Засновником еволюційної економічної парадигми являється Йозеф Шумпетер, але фактично його теорії на час заснування не утворили окремої економічної школи 
достатньої вагомості, лише з часом використання його досліджень суттєво вплинуло на розвиток економічної науки. Найбільший розвиток еволюційна парадигма отримала на сучасному етапі. Основними представниками парадигми економічного еволюціонізму являються: Р. Нельсон, С. Уінтер, Дж. Ходжсон, Д. Норт, Л.І. Абалкін, В.І. Макаров та ін. Основними положення еволюційної економічної парадигми являються: встановлення пріоритету інноваційного розвитку; концентрація економічної політики на проблемах відтворення інститутів; розширення застосування еволюційної теорії ігор та економетрики для дослідження динаміки розвитку економічних структур; використання міждисциплінарного порівняльного адаптивного переносу (економічний аналіз на основі біологічних аналогій) [11].

Наступною для розгляду є системна економічна парадигма, яка виникла на основі міждисциплінарного підходу. Такий підхід сформувався на базі дослідження та економічної інтерпретації загальної теорії систем Л. Фон Берталанфі, яка була розроблена ним у 1969 р. Системна економічна парадигма розвивалася в дослідженнях: Я. Корнаї, Г. Клейнера. Основними положеннями системної економічної парадигми являються: пріоритет дослідження економіки як сукупності взаємодіючих систем; аналіз економічних процесів на основі виділення системних факторів та мотивів поведінки економічних агентів; пріоритет розробки взаємно кореспондуючої типології економічних систем, економічних процесів та економічних благ; встановлення суттєвих взаємозв'язків між різними класами елементів типології; виділення стратегії управління економічними системами різних типів; обгрунтування структурної моделі взаємодії компонентів системної економіки; дослідження процесів утворення та функціонування стійких комплексів економічних систем [12;13; 14; 15].

Синергетична економічна парадигма також виникла на основі міждисциплінарного підходу, в результаті економічної інтерпретації досліджень фізика-теоретика Г. Хакена, а також розвитку його ідей в працях I. Пригожина, С. Курдюмова, І. Добронравової та ін. Синергетична економічна парадигма розвивалась в працях В. Князевої, В. Занга, А. Колєснікова, Т. Колєснікової, Б. Кузнєцової, В. Аршинова, В. Решетило, І. Лукінова та ін. Основними положення синергетичної економічної парадигми являються: встановлення такого переліку апріорних характеристик 
економічних систем: відкритість, нерівноважність, незворотність розвитку, нелінійність, дуальність; встановлення пріоритету ідентичності розвитку економічних систем процесам еволюції дисипативних структур; інтерпретація економічних процесів на основі виділення типів та етапів самоорганізації системи; економічне обгрунтування теорії формування атрактору як основного напряму розвитку економічних процесів; використання поняття флуктаційного хаосу та точок біфуркації для інтерпретації нерівноважних станів економічної системи та динаміки ії розвитку; обгрунтування нелінійності процесів розвитку економічних систем та нелінійного реагування на зовнішній вплив; обгрунтування самоорганізації та саморозвитку як єдиної цілісної форми еволюції економічних систем $[16 ; 17 ; 18 ; 19 ; 20]$.

Таким чином, було здійснено парадигмальну інтерпретацію еволюції економічної науки на основі застосування розгорнутого критерію, який спирається на виділення найбільш значних наукових шкіл, які вплинули на зміну траєкторії іiі розвитку. Тим не менше, такий критерій не являється вичерпним для побудови парадигмальної моделі, оскільки по мірі збільшення диференціації економічних досліджень важлива їх комплексна парадигмальна інтерпретація, що можливо на основі використання міждисциплінарного принципу.

\section{4. Парадигмальна ідентифікація із застосуванням сутнісного конкретизованого критерію} та виділення типу економічного агенту

Застосування сутнісного конкретизованого критерію для інтерпретації парадигмального розвитку економічної науки являється альтернативним та більш об'єктивним, оскільки дозволяє згрупувати економічні парадигми за визначеною ознакою на основі їх парадигмального вкладу в розвиток економічно теорії, та ідентифікувати їх парадигмальний тип. Такий критерій надає змогу виділити комплекси парадигм економічного розвитку, які відображають глобальну парадигмальну еволюцію економічної науки (таблиця 2).

Отже, якщо порівнювати парадигмальний розвиток економічної науки на основі сутнісного конкретизованого критерію згідно класифікації С. Стьопіна, то можна відмітити, що він відбувався за принципом часових лагів порівняно з парадигмальним розвитком природознавчих наук. При- 
Таблиця 2

Комплекси парадигм економічного розвитку, які відображають глобальну парадигмальну еволюцію економічної науки

\begin{tabular}{|c|c|c|c|}
\hline Період & $\begin{array}{l}\text { Економічні } \\
\text { парадигми }\end{array}$ & \begin{tabular}{|c|} 
Парадигмальний \\
тиI
\end{tabular} & Системні об'єкти \\
\hline $\begin{array}{c}\text { Починаючи з } \\
\text { XVI ст. до другої } \\
\text { половини XVIII ст. }\end{array}$ & $\begin{array}{c}\text { Меркантилістська } \\
\text { Фізіократична }\end{array}$ & $\begin{array}{c}\text { Докласична } \\
\text { раціональність }\end{array}$ & Прості системи \\
\hline $\begin{array}{c}3 \text { середини } \\
\text { XVIII ст. до кінця } \\
\text { XIX ст. }\end{array}$ & $\begin{array}{c}\text { Класичної } \\
\text { політичної } \\
\text { економії } \\
\text { Марксистська }\end{array}$ & $\begin{array}{c}\text { Класична } \\
\text { раціональність }\end{array}$ & Складні системи \\
\hline $\begin{array}{c}3 \text { кінця XIX ст. } \\
\text { до першої чверті } \\
\text { XX ст. }\end{array}$ & $\begin{array}{c}\text { Маржиналістська } \\
\text { Неокласична }\end{array}$ & $\begin{array}{c}\text { Некласична } \\
\text { раціональність }\end{array}$ & $\begin{array}{c}\text { Складні } \\
\text { саморегулюючі } \\
\text { системи } \\
\end{array}$ \\
\hline $\begin{array}{c}3 \text { першої чверті } \\
\text { ХХ ст. до } \\
\text { останньої чверті } \\
\text { ХХ ст. }\end{array}$ & $\begin{array}{c}\text { Кейнсіанська } \\
\text { Інституціональна }\end{array}$ & $\begin{array}{l}\text { Модифікована } \\
\text { некласична } \\
\text { раціональність }\end{array}$ & $\begin{array}{c}\text { Складні } \\
\text { саморегулюючі } \\
\text { системи }\end{array}$ \\
\hline $\begin{array}{c}3 \text { останньої } \\
\text { чверті XX ст. до } \\
\text { сучасного часу }\end{array}$ & $\begin{array}{c}\text { Економічного } \\
\text { еволюціонізму } \\
\text { Системної } \\
\text { економіки } \\
\text { Синергетичної } \\
\text { економіки }\end{array}$ & $\begin{array}{c}\text { Постнекласична } \\
\text { раціональність }\end{array}$ & $\begin{array}{c}\text { Складні } \\
\text { саморорозвиваючі } \\
\text { системи }\end{array}$ \\
\hline
\end{tabular}

Джерело: опраџьовано авторами за джерелом [21]

чому важливо відмітити, що розвиток економічної науки в парадигмальному вимірі має дещо відмінну структуру, що зумовлено складно-системним іiі розвитком. Така особливість викликана специфічною взаємною дифузією економічних теорій, яка призводила до виникнення нових парадигм. Uа основі порівняльної систематизації розгорнутого критерію та сутнісного конкретизованого критерію можливо здійснити хронологічну систематизацію парадигмального розвитку економічної науки.

Тим не менш, використання сутнісного конкретизованого критерію також не є виключним, оскільки недостатньо відображає бачення та ідентифікацію економічного агенту в процесі парадигмальної еволюції економічної теорії, тобто власне людини, як центральної детермінуючої сутності розвитку економічної науки та економіки взагалі. Така інтерпретація стала 
можлива в період, коли економічна наука пройшла досить тривалий еволюційний шлях та досягла необхідного рівня ускладнення та диференціації.

Отже, використовуючи критерій ідентифікації типу економічного агенту як ядра парадигмального розвитку, можливо проведення альтернативної інтерпретації економічних парадигм. Даний напрям досліджень представлений в працях Г. Клейнера, В. Чужикова, О. Федірко та інших авторів. Так, Г. Клейнер здійснює таке виділення парадигмальних етапів еволюції економічної науки на основі диференціації економічних агентів (таблиця 3).

Таблиця 3

\section{Сучасні парадигмальні етапи еволюції економічної науки на основі диференціації економічних агентів}

\begin{tabular}{|c|c|c|c|}
\hline $\begin{array}{c}\text { Парадигмальний } \\
\text { етап }\end{array}$ & Період & $\begin{array}{c}\text { Домінуюча } \\
\text { парадигма }\end{array}$ & Економічний агент \\
\hline I & $1920-1980$ роки & $\begin{array}{c}\text { Сучасна } \\
\text { неокласична } \\
\text { парадигма }\end{array}$ & $\begin{array}{c}\text { Ното есопотісиs } \\
\text { (неокласична людина) }\end{array}$ \\
\hline II & $1920-1990$ роки & $\begin{array}{c}\text { Iнституціональна } \\
\text { парадигма }\end{array}$ & $\begin{array}{c}\text { Ното institutius } \\
\text { (інституціональна } \\
\text { людина) }\end{array}$ \\
\hline III & $1980-2000$ роки & $\begin{array}{c}\text { Еволюційна } \\
\text { парадигма }\end{array}$ & $\begin{array}{c}\text { Ното еvolutius } \\
\text { (еволюційна людина) }\end{array}$ \\
\hline IV & $\begin{array}{c}1990 \text { роки - } \\
\text { сучасний час }\end{array}$ & $\begin{array}{c}\text { Системна } \\
\text { парадигма }\end{array}$ & $\begin{array}{c}\text { Ното systemus } \\
\text { (системна людина) }\end{array}$ \\
\hline
\end{tabular}

Джерело: опращьовано авторами за джерелом [22]

При такій диференціації кореляцію економічної парадигми 3 певним типом економічного агенту можна визначити у виглядів такої таблиці (таблиця 4).

B.I. Чужиков, грунтуючись на дослідженнях Р. Сведберга, здійснює виділення парадигм на основі ідентифікації економічного агенту за дещо іншою ознакою, яка, тим не менш, корелює 3 поглядами Г. Клейнера. Так, при проведенні загальної систематизації поглядів економістів другої половини XX ст. згідно даної позиції, глобальні парадигми диференціюються на дві глобальні наднаукові парадигми - неокласичну та соціальну. Відповідно економічними агентами 


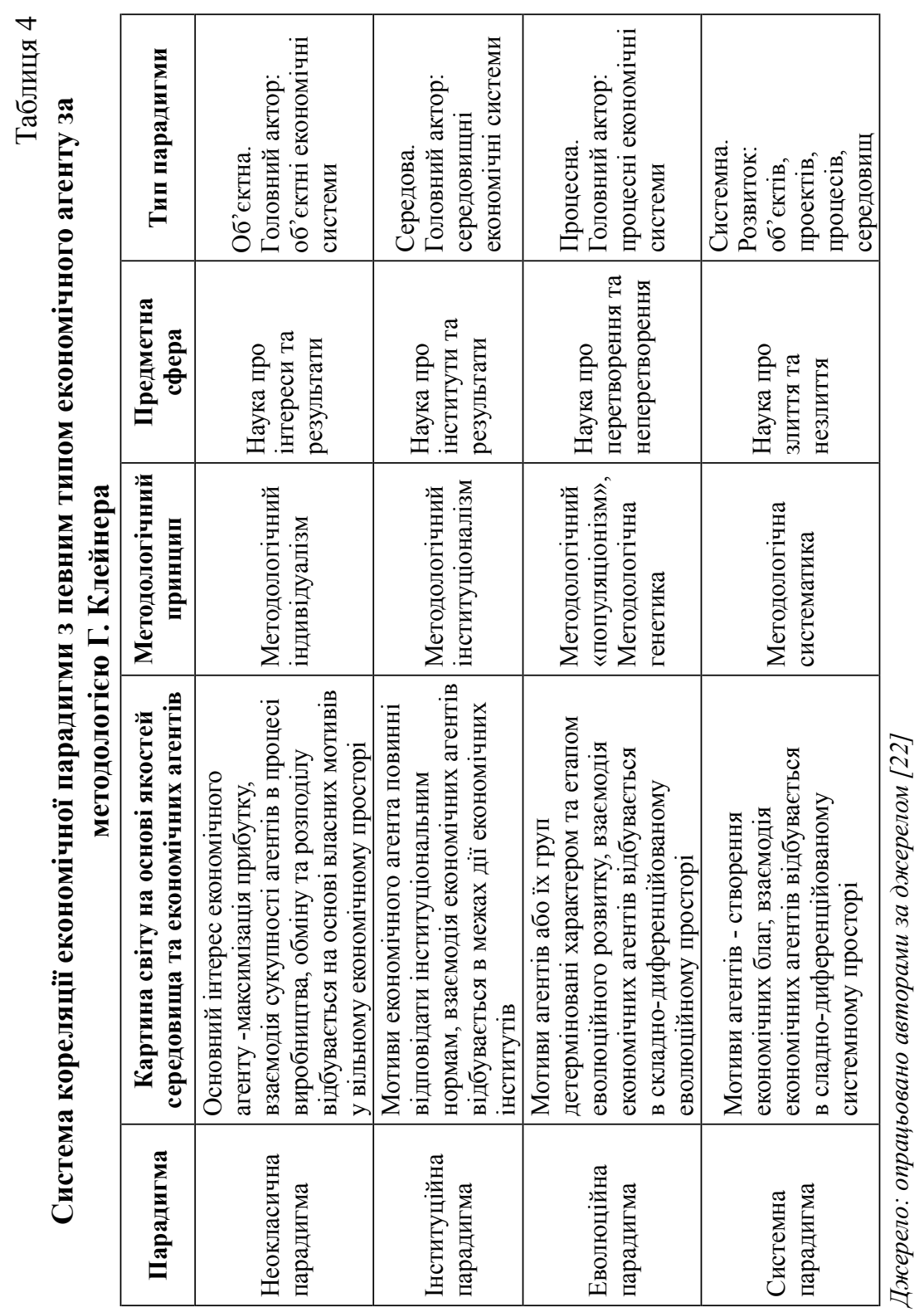


в даному випадку являються Homo economicus та Homo sociologicus [23, с. 92], які відповідають двом типам ідеалізованої абстрактної сутності людини як суб'єкта соціально-економічних відносин.

Якості таких економічних агентів було систематизовано В. Чужиковим у наступному вигляді (таблиця 5).

Таблиця 5

Неокласична та соціальна парадигма як віддзеркалення світу (друга половина XX ст.) за Р. Сведбергом (1991р.)

\begin{tabular}{|l|l|l|}
\hline \multicolumn{1}{|c|}{ Дія } & \multicolumn{1}{|c|}{ Ното есопотісиs } & \multicolumn{1}{c|}{ Ното sосіоlogicus } \\
\cline { 2 - 3 } Принцип дії & Свдивідуальна & \multicolumn{1}{c|}{ Колективна } \\
\hline Мотиви дії & Раціональні обрахунки & $\begin{array}{l}\text { Обмеженість дії через } \\
\text { наявну соціальну структуру } \\
\text { традиції та цінності }\end{array}$ \\
\hline Арена дії & Ринок & $\begin{array}{l}\text { Все суспільство разом 3 } \\
\text { ринком }\end{array}$ \\
\hline Визначальний принцип & $\begin{array}{l}\text { Кратність, } \\
\text { децентралізація рішень }\end{array}$ & $\begin{array}{l}\text { Рішення, обумовлені соціаль- } \\
\text { ною та політичною владою }\end{array}$ \\
\hline $\begin{array}{l}\text { Типи концепцій, що } \\
\text { використовуються }\end{array}$ & $\begin{array}{l}\text { Аналітичні та } \\
\text { абстрактні }\end{array}$ & Емпіричні та описові \\
\hline Завдання аналізу & $\begin{array}{l}\text { Передбачення як } \\
\text { пояснення }\end{array}$ & Опис як поняття \\
\hline Відношення до інших наук & Самодостатність & Самодостатність \\
\hline
\end{tabular}
Джерело: [23]

Фактично в даному випадку Homo sociologicus Р. Сведберга та Ноmo institutius Н. Клейнера мають ідентичні якості, та за сутністю являються одним типом економічного агенту. Ідентифікація напряму наукового розвитку, який відповідає такому типу економічного агенту, також являється ідентичною та різниться лише за рівнем секторальної спеціалізації і представлена інституціоналізмом як економічним напрямом соціологічної науки. B.I. Чужиков виділяє третій тип економічного агенту, який уособлює третю глобальну парадигму, а саме Homo informaticus, який виникає як наслідок процесів еволюції та модернізації, які стали основою утворення інформаційного суспільства [24, с. 37]. Причому такий тип агенту формується внаслідок взаємодії секторальних та горизонтальних парадигм, і таким чином являється обгрунтуванням його 
глобальної детермінації. Натомість аналізуючи методологію Н. Клейнера згідно виділення типів Homo evolutius та Homo systemus, можна стверджувати, що вони $є$ скоріше економічними агентами секторальних економічних парадигм. Разом з тим, якщо враховувати аналіз сучасного періоду градації економічної науки, який було здійснено вище, можна також виділити інший тип економічного агенту, який виникає в рамках розвитку економічної синергетики, а саме Homo synergeticus. Такий тип економічного агенту вирізняється якістю, яка грунтується на співвідношенні двох самоорганізуючих систем, а саме людини та економіки. Причому в даному випадку відбувається взаємна детермінація впливу, та постає питання виявлення тенденцій розвитку однієї самоорганізуючої системи - людини, яка існує у внутрішньому середовищі іншої самоорганізуючої системи - економіки. Тим не менш, така парадигмальна основа, хоча і має міждисциплінарний характер, який власне притаманний і системній парадигмі, має виражену секторальну дію.

О. Федірко, продовжуючи дослідження В. Чужикова, та використовуючи подібну методологію обгрунтовує четвертий тип економічного агенту, а саме Ноmo retis (людину мережеву), який виникає внаслідок активізації інноваційного детермінізму розвитку суспільства загалом та економіки зокрема. Так, автор констатує, що представлене розуміння складових елементів парадигми, ядром якої $\epsilon$ homo retis, базується на дослідженні колабораційної соціально-економічної взаємодії, яка значною мірою відображає конгломерат інтересів основних акторів глобального господарства [25, с. 25]. На основі обгрунтування даної парадигми О. Федірком було розроблено порівняльну таблицю якостей нових типів економічних агентів (таблиця 6).

Таким чином, порівнюючи погляди Н. Клейнера, В. Чужикова та О. Федірко, і аналізуючи проведення ними ідентифікації парадигмальної градації за ознакою типу економічного агенту, можна стверджувати, що ії динаміка детермінується тенденціями формування єдиної парадигми економічного розвитку, яка повинна носити міжсекторний характер свого обгрунтування й надавати відповіді та рішення на виклики й проблеми сучасного часу.

Тим не менш, фактичне виникнення сучасної парадигми економічного розвитку, на нашу думку, знаходиться в стадії формування, що можна ідентифікувати як останній етап перед утворенням їі стійкого 
Таблиця 6

Порівняльний аналіз якостей нових типів економічних агентів як детермінант нових парадигм

\begin{tabular}{|c|c|c|}
\hline & Homo informaticus & Homo retis \\
\hline Дія & $\begin{array}{l}\text { Індивідуальна, } \\
\text { віртуалізована }\end{array}$ & $\begin{array}{c}\text { Колабораційна, яка } \\
\text { відображає конгломерат } \\
\text { інтересів }\end{array}$ \\
\hline Принцип дії & $\begin{array}{l}\text { Свобода дії з неявною } \\
\text { регламентацією у разі } \\
\text { глобальної загрози }\end{array}$ & $\begin{array}{l}\text { Свобода дії в межах правил, } \\
\text { встановлених у мережах }\end{array}$ \\
\hline Мотиви дії & $\begin{array}{l}\text { Сприйняття світу через } \\
\text { створення та нагромадження } \\
\text { знань і капіталу, активний } \\
\text { трансфер інформації } \\
\end{array}$ & $\begin{array}{l}\text { Отримання синергії } \\
\text { у системі колабораційних } \\
\text { відносин }\end{array}$ \\
\hline Арена дії & $\begin{array}{l}\text { Віртуальний світ, глобальний } \\
\text { ринок }\end{array}$ & $\begin{array}{l}\text { Глобальне мережеве } \\
\text { суспільство }\end{array}$ \\
\hline $\begin{array}{l}\text { Визначальний } \\
\text { принцип }\end{array}$ & \begin{tabular}{|l|} 
Неявна централізація рішень, \\
що визначається технократією
\end{tabular} & \begin{tabular}{|l} 
Неявна мережева \\
централізація рішень
\end{tabular} \\
\hline $\begin{array}{l}\text { Типи концепцій, що } \\
\text { використовуються }\end{array}$ & $\begin{array}{l}\text { Системні, поліструктурні, } \\
\text { аналітичні, емпіричні, } \\
\text { абстрактні }\end{array}$ & $\begin{array}{l}\text { Системні, поліструктурні, } \\
\text { аналітичні, емпіричні, } \\
\text { абстрактні }\end{array}$ \\
\hline Завдання аналізу & $\begin{array}{l}\text { Прогноз у межах часових } \\
\text { лагів }\end{array}$ & $\begin{array}{l}\text { Визначення функцій } \\
\text { та ефективності } \\
\text { колабораційних зв’ язків } \\
\end{array}$ \\
\hline $\begin{array}{l}\text { Відношення до } \\
\text { інших наук }\end{array}$ & Самодостатність & Самодостатність \\
\hline
\end{tabular}

Джерело: [25]

фундаменту. Ще одним з ключових моментів в даному випадку являється рівень адаптивності парадигми, якщо розглядати іiі як фундамент для детермінації економічних досліджень. Так, утворення нового типу економічного агенту може відбуватися з різною інтенсивністю у вигляді часових лагів різної протяжності, залежно від концентрації в локальних елементах глобального простору. Тому, у разі використання певної парадигми як детермінанти економічних досліджень, вона повинна відповідати превалюючому рівню економічних агентів в локальному територіальному просторі, при формуванні економічної політики - національному. Останні два типи економічних агентів, в національному соціально-економічному просторі не представлені домінуючою кількістю, а отже не можуть розглядатися як основна детермінанта регулювання економічних процесів на рівні держави. 


\section{5. Висновки}

Парадигмальна основа сучасної державної політики економічного розвитку, на нашу думку, повинна базуватися на парадигмі Ното sociologicus, якщо розглядати парадигмальну основу за критерієм виділення типу економічного агенту. Така позиція зумовлена насамперед можливістю використовувати стійкий детермінізаційний фундамент даної парадигми, враховуючи необхідність збереження соціального центризму при забезпеченні розвитку економіки. Оскільки на сучасному етапі економічний розвиток національного господарства неможливо підтримувати на достатньому рівні його інтенсивності без формування стійкого інтеграційного вектору, комунікаційний рівень парадигмальної основи структурної політики повинен бути відповідним.

Така парадигмальна основа має достатньо високий комунікаційний рівень, що може забезпечити стійку позитивну динаміку взаємодії національного та глобального економічного простору. Найвищий соціальний пріоритет також відповідає тенденціям розвитку європейських економічних систем, інтеграція в об'єднання яких являється найбільш оптимальним вектором розвитку національної економіки України. Але, глобальна парадигма, яка являється фундаментом для формування державної політики економічного розвитку, що реалізується в сучасних умовах інтеграційних процесів, не виключає можливості пошуку нової парадигмальної основи, яка здатна більш ефективно обгрунтувати та сформувати оптимальні шляхи вирішення викликів сучасності.

При цьому важливим є врахування перспектив використовувати можливості інтерпретації економічної дійсності за допомогою галузевих новітніх економічних парадигм. Така позиція зумовлена необхідністю пошуку та вироблення синтетичної адаптованої, ефективної позиції щодо аналізу та управління економічними процесами, які відбуваються в національному економічному просторі. Так, за розширеним критерієм найбільш прогресивними парадигмами в їх галузевому вимірі являються еволюційна, синергетична та системна, що за сутнісним критерієм представляють собою елементи загальної постнекласичної парадигми. На нашу думку, дані парадигми не являються антагоністичними, а скоріше доповнюють одна одну, з метою найбільш оптимальної інтерпретації особливостей економічних процесів різних рівнів. 


\section{Список літератури:}

1. Федосеев П.Н., Ковалёв С.М., Панов В.Г. Философский энциклопедический словарь / гл. ред. Л.Ф. Ильичёв. Москва: Советская энциклопедия, 1983. $840 \mathrm{c}$

2. Кун Т. Структура научных революций. С вводной статьей и дополнениями. Москва, 1969. 300 с.

3. Лебедев С.А. Философия науки: Словарь основных терминов. Москва, 2004. $320 \mathrm{c}$.

4. Dosi G. Technological Paradigms and Technological Traectories: a Suggested interpretation of the Determinants of Technical Change. Research Policy. 1982. Vol. 11. P. 147-162.

5. Фуко М. Слова и вещи. Археология гуманитарных наук. СанктПетербург, 1994. 408 с.

6. Лакатос И. Фальсификация и методология научно-исследовательских программ, 1995.

7. Яковец Ю.В. Предвидение будущего: парадигма цикличности. Москва, 1992. $109 \mathrm{c}$.

8. Степин В.С. Классика, неклассика, постнеклассика: критерии различения. Постнеклассика: философия, наука, культура. Санкт-Петербург, 2009. C. 249-295.

9. Яковец Ю. В. Формирование постиндустриальной парадигмы: Истоки и перспективы. Вопросы философии. 1997. № 1. С. 14-20.

10. Степин В.С. Основания науки и их социокультурная размерность. Научные и вненаучные формы мышления: материалы международного симпозиума (4-9 апреля 1995 г.). Москва, 1996.

11. Сударев О.И. Истоки эволюционной парадигмы в экономической теории. Terra Economicus. 2008. Т. 6. № 3. С. 81-87.

12. Kornai J. The system Paradigm. William Davidson Institute Working Papers. Series 278. 1998. 26 p.

13. Клейнер Г.Б. Системная парадигма и экономическая политика. Общественные науки и современность. 2007. № 2. С. 99-114.

14. Клейнер Г.Б. Системная парадигма и теория предприятия. Bonpocbl экономики. 2002. № 10. С. 47-69.

15. Клейнер Г.Б. Системная экономика как платформа развития современной экономической теории. Системный анализ в экономике-2012: материаль научно-практической конференщии. (27-28 ноября 2012). Москва, 2012. С. 31.

16. Колесникова Т.А. Основные понятия и принципы синергетики социально-экономических систем. Синергетика и проблемы теории управления. 2004. С. 482-495.

17. Князева Е.Н., Курдюмов С.П. Основания синергетики: Синергетическое миропонимание. Москва, 2010.

18. Занг В.Б. Синергетическая экономика. Время и перемены в нелинейной экономической теории. Москва, 1999. 335 с.

19. Аршинов В.И. Синергетика как феномен пост-неклассической науки. Москва, 2013. 206 с. 
20. Решетило В.П. Экономическая синергетика институциональных изменений. Харьков, 2006. 288 с.

21. Рыбачук М.А. Диалектика взаимодействия общенаучных и дисциплинарных парадигм (на примере естествознания и экономики). Журнал экономической теории. 2016. № 1. С. 114-122.

22. Клейнер Г. Системная экономика - новое направление в экономической теории. Казань, 2012.

23. Чужиков В.О. Глобальна регіоналістика: історія та сучасна методологія: Монографія. Київ, 2008. 272 с.

24. Чужиков B.I., Гончарова А.О. Зміна глобальних парадигм: наслідки для машинобудівної галузі. Економічний простір. 2013. № 71. С. 34-46.

25. Федірко О. Формування нової локально-інноваційної парадигми регіональних досліджень. Регіональна економіка. 2015. № 3. С. 24-33.

\section{References:}

1. Il'ichev L.F., Fedoseev P.N., Kovalev S.M., Panov V.G. (1983). Filosofskiy entsiklopedicheskiy slovar' [Philosophical Encyclopedic Dictionary]. Moscow: Sovetskaya entsiklopediya. (in Russian)

2. Kun T. (1969). Struktura nauchnykh revolyutsiy. $S$ vvodnoy stat'ey $i$ dopolneniyami [The structure of scientific revolutions. With introductory article and additions]. Moscow: Progress. (in Russian)

3. Lebedev S.A. (2004). Filosofiya nauki: Slovar'osnovnykh terminov [Philosophy of Science: Glossary of Key Terms]. Moscow: Akademicheskiy Proekt. (in Russian)

4. Dosi G. (1982). Technological Paradigms and Technological Traectories: a Suggested interpretation of the Determinants of Technical Change. Research Policy. Vol. 11. P. 147-162.

5. Fuko M. (1994). Slova i veshchi. Arkheologiya gumanitarnykh nauk [Words and things. Archeology of the Humanities]. St. Petersburg: A-cad. (in Russian)

6. Lakatos I. (1995). Fal'sifikatsiya i metodologiya nauchno-issledovatel'skikh programm [Falsification and methodology of research programs]. (in Russian)

7. Yakovets Yu. (1992). Predvidenie budushchego: paradigma tsiklichnosti [Foresight of the Future: The Cyclical Paradigm]. Moscow: B.I. (in Russian)

8. Stepin V.S. (2009). Klassika, neklassika, postneklassika: kriterii razlicheniya [Classics, non-classics, post-non-classics: criteria for distinguishing]. St. Petersburg: Izdatel'skiy dom Mir. (in Russian)

9. Yakovets Yu. (1997). Formirovanie postindustrial'noy paradigmy: Istoki $i$ perspektivy [The Formation of a Post-Industrial Paradigm: Origins and Prospects]. Philosophy Issues, vol. 1, pp. 14-20.

10. Stepin V.S. (1996). Osnovaniya nauki i ikh sotsiokul'turnaya razmernost' [The foundations of science and their sociocultural dimension]. Proceedings of the Nauchnye $i$ vnenauchnye formy myshleniya: Mezhdunar. simpozium (Moscow, 1996). Moscow: Kil'.

11. Sudarev O.I. (2008). Istoki evolyutsionnoy paradigmy v ekonomicheskoy teorii [The origins of the evolutionary paradigm in economic theory]. Terra Economicus, vol. 6, no. 3, pp. 81-87. 
12. Kornai J. The system Paradigm. William Davidson Institute Working Papers. Series 278. 1998. 26 p.

13. Kleyner G.B. (2007). Sistemnaya paradigma i ekonomicheskaya politika [Systemic paradigm and economic policy]. Social sciences and modernity, vol. 2, pp. 99-114.

14. Kleyner G.B. (2002). Sistemnaya paradigma i teoriya predpriyatiya [Systemic paradigm and enterprise theory]. Economic issues, vol. 10. pp. 47-69.

15. Kleyner G.B. (2012). Sistemnaya ekonomika kak platforma razvitiya sovremennoy ekonomicheskoy teorii [System economics as a platform for the development of modern economic theory]. Proceedings of the Sistemnyy analiz $v$ ekonomike: nauchno-prakticheskaya konferentsiya, p. 31 .

16. Kolesnikova T.A. (2004). Osnovnye ponyatiya i printsipy sinergetiki sotsial'no-ekonomicheskikh sistem [Basic concepts and principles of synergetics of socio-economic systems]. Synergetics and problems of control theory, pp. 482-495.

17. Knyazeva E.N. (2010). Osnovaniya sinergetiki: Sinergeticheskoe miroponimanie [The Foundations of Synergetics: A Synergetic Worldview]. Moscow: Knizhnyy dom "Librokom". (in Russian)

18. Zang V.B. (1999). Sinergeticheskaya ekonomika. Vremya i peremeny $v$ nelineynoy ekonomicheskoy teorii [Synergetic economy. Time and Change in Nonlinear Economics]. Moscow: Mir. (in Russian)

19. Arshinov V.I. (2013). Sinergetika kak fenomen post-neklassicheskoy nauki [Synergetics as a phenomenon of post-non-classical science]. Moscow: Directmedia. (in Russian)

20. Reshetilo V.P. (2006). Ekonomicheskaya sinergetika institutsional'nykh izmeneniy [Economic Synergetics of Institutional Changes]. Khar'kov: PrometeyPres. (in Russian)

21. Rybachuk M.A. (2016). Dialektika vzaimodeystviya obshchenauchnykh $i$ distsiplinarnykh paradigm (na primere estestvoznaniya i ekonomiki). [Dialectics of the interaction of general scientific and disciplinary paradigms (on the example of natural science and economics).]. Journal of Economic Theory, vol. 1, pp. 114-122.

22. Kleyner G. (2012). Sistemnaya ekonomika - novoe napravlenie $v$ ekonomicheskoy teorii [Systemic economics - a new direction in economic theory]. Kazan': Tsentral'niy ekonomiko-matematicheskiy institut RAN, KFU. (in Russian)

23. Chuzhykov V.O. (2008). Ghlobaljna reghionalistyka: istorija ta suchasna metodologhija: Monoghrafija [Global Regionalism: History and Modern Methodology: A Monograph]. Kyiv: KNEU. (in Ukrainian)

24. Chuzhykov V.I., Ghoncharova A.O. (2013). Zmina ghlobaljnykh paradyghm: naslidky dlja mashynobudivnoji ghaluzi [Changing global paradigms: implications for the engineering industry]. Economic space, vol. 71, pp. 34-46.

25. Fedirko O. (2015). Formuvannja novoji lokaljno-innovacijnoji paradyghmy reghionaljnykh doslidzhenj [Formation of a new locally innovative paradigm for regional research]. Regional economy, vol. 2015, pp. 24-33. 